\title{
THE CHANGING ROLE OF MANAGEMENT ACCOUNTING SYSTEMS TOWARDS VALUE CREATION
}

\author{
Edita Gimžauskienè \\ Kaunas University of Technology, Lithuania \\ edita.gimzauskiene@ktu.lt \\ Loreta Valančienè \\ Kaunas University of Technology, Lithuania \\ loreta.valanciene@ktu.lt
}

October 2007

\begin{abstract}
Value concepts with a multi-stakeholder approach in the management accounting field are the subject of recent interest. The most popular management accounting conceptions, namely, activity-based costing (management) and balanced scorecard, reveal how the changed management accounting role integrates a focus on three key stakeholder groups: employees, customers and shareholders. Built on previous management accounting studies, this article explores when the management accounting system ensures value creation. The relationship between value creation and the management accounting system were disclosed using the multistakeholder theoretical approach. Research methods adopted in this study are empirical survey and empirical field study. The implementation level of modern management accounting conceptions was analysed using quantitative data (survey). Deeper analysis was performed in a Lithuanian organisation disclosing relationships between value creation and the implementation level of management accounting conceptions (case study). The results of the research revealed that modern management accounting conceptions might be a precondition for the changing role of management accounting but it depends on the implementation level and the organisation's ability to manage all capacities of these conceptions.
\end{abstract}

\section{Keywords:}

Management accounting system, value-based management, value creation, balanced scorecard, activity-based costing 


\section{INTRODUCTION}

The preconditions of a knowledge economy have influenced global changes, which consequently had an impact on the value-creation drivers. Thus the nature of decisions had changed as well. This situation determined the popularity of modern management accounting tools: activitybased costing management ( $A B C M$ ) and balanced scorecard (BSC). According to the theoretical assumptions of those conceptions the implementation of those tools should assist in measuring, planning, evaluating and managing the value-creation process inside an organisation. But the results of recent research in the management accounting field did not provide definite confirmation of this aspect (Innes \& Mitchell, 1990; Burns \& Scapens, 2000).

Management accounting studies disclosed the significance of management accounting as a stimulus for organisational change and progress. They substantiated the benefit of the performance measurement process not only for financial results (improving financial indicators, increasing market value) but also for ongoing performance improvement, communication and control processes. This scientific field was researched from various angles by Demsi and Bainen (1987), Balakrishan, et al. (1996), Kennedy and Graves (2001), Malina and Selto (2001). Studies on organisational change, as a stimulus for management accounting changes, were aimed at determining volatile economic principles that challenge changes in organisations and information demand, simultaneously considering their nature. Extensive research and comparative studies on these related issues have been performed worldwide, including postcommunist countries. Studies on management accounting changes were conducted by Hoque and Hopper (Bangladesh, 1994), Libby and Waterhouse (Canada, 1996), Alam (Bangladesh, 1997) Dent (World-wide, 1996), Granlund and Lukka (Finland, 1998), Laitinen (Finland, 1999), Anderson and Lannen (India, 1999), Wnuk and Sobanska (Poland, 2000), Haldma and Laats (Estonia, 2000), Luther and Longden (South Africa, 2001). These studies were based on conceptual contributions by Innes and Mitchell (1990), Kellet and Sweeting (1991), Coates, et al. (1992), Cobb and Helliar (1995) as well as Burns and Scapens (2000).

The research findings indicate that analogous ideas and methods are used worldwide in management accounting. However, findings from national studies demonstrate that the changing environment of organisational performance has a direct impact on changes in management accounting that in turn are realised in close connection with projects on reorganising internal management systems. Research has proved that new management accounting methods are promptly adapted by the business organisations in innovative countries (Lithuania could be allotted to this group as well, though special in-depth research was not carried out in this country). Therefore, the greater the demand for management change is, the faster the change in management accounting occurs.

Changes of present day management are focused on value creation. According to this approach stakeholder value is the result of thousands of everyday decisions made by individuals in a corporation. Stakeholder value is created or destroyed by one decision at a time. Management consultants and researchers agree that the creation of value is seen as a new source of competitive advantage. The questions to be asked "What role might management accounting play in creating and sustaining this competitive advantage?" and "Have the new conceptions of management accounting changed the role of management accounting itself?" Are these revised management accounting conceptions sufficient to meet new management challenges? In what way do management accounting systems influence value creation? 
The paper's aim is to disclose when management accounting systems ensure value creation. Evolution of the value creation concept and changes of management accounting are analysed in the first part of the paper from a theoretical point of view. The relations between value creation and the implementation level of modern management accounting concepts, namely, ABCM and $B S C$, are explored as well. The research method is briefly discussed in the second part. The implementation level of modern management accounting conceptions is analysed using quantitative data (survey). Deeper analysis was performed in a Lithuanian organisation disclosing relationships between value creation and the implementation level of management accounting conceptions (case study). The results and their interpretation are presented in the third part.

\section{THEORETICAL BACKGROUND}

\subsection{Evolution of the value-creation concept}

Currently, management accounting is a valuable service supporting a wide range of strategic and tactical management decisions. The most important of them is measuring and tracking the value-creation process. Findings from the literature on value studies demonstrate that there are different opinions about value creation. One group of researchers states that companies should create value for customers, recognising their requirements and offering them professional and helpful service (Novack, et al., 1995; Woodruff, 1997; Grönroos, 1997; etc.); another group declares that companies should create value not only for the customer, but also for their shareholders (Wenner \& Leber, 1989; Stewart, 1991; Byrne \& Markham, 1994; etc.); and the third group of researchers argue that companies should create value for all stakeholders - i.e., a multi-stakeholder approach (Reichheld, 1996; Heskett, et al., 1997; Payne, et al., 2001; etc.).

The multi-stakeholder approach reveals a new stream of value research. This approach is endorsed by Reichheld (1996), who argues that key stakeholders - employees, customers and shareholders - are the 'forces of loyalty' and, while other stakeholders can have a major role to play, it is these three that are central in achieving success. Payne and Holt (2001) contend that three stakeholder groups are emerging as the core focus for organisations in terms of value management and performance improvement. It means that organisations need to focus on these groups for creating and providing value (employee value, customer value and shareholder value) as well as for maximising and measuring their profitability and performance. In implementing a value management approach, organisations need to adopt an integrated approach to managing these stakeholders by focusing on the linkages between employee value, customer value and shareholder value.

In addition, value creation could be discussed using the sustainable cycle of value-creation approach, suggested by Martin and Petty (2000). These researchers noted that value creation depends on key elements of sustainable cycle: value creation (identification of opportunity, strategy formulation and operations), measurement/ assessment (methods of valuations and measures), rewards (incentives and motivation systems). The fundamental premise for such point of view is that in order to sustain the wealth-creation process, managerial performance must be measured (creation of customer value) and rewarded (creation of employee value) using metrics that can be linked directly to profit and growth (creation of shareholder value).

Those findings allow us to propose that an organisation requires the integral consideration of the value perspectives and key elements of sustainable cycle, which is impossible to achieve 
without a relevant measurement system. Can a management accounting system ensure it? What are the advantages of modern management accounting conceptions (activity-based costing, balanced scorecard) as compared to the conventional ones? There are some important factors that impede the realisation of an integral approach to the conventional management accounting system. They are as follows:

- Lack of functional integration between different departments and communication between management levels (Storbacka, 1997; Caru \& Cugini, 1999);

- The same concepts tend to mean different things to people in sales and marketing departments and to the management accountants - in other words, discrepancy between the notions (Storbacka, 1997; Blattberg, et al., 2001);

- Existing tools cannot easily identify how to integrate measurements and interpretations of company phenomena in a double perspective of market effectiveness and internal efficiency (Simons, 2000).

It can be stated that analysis of value-creation research calls for the development of measuring techniques which are designed to capture information in all aspects of business and allow the language of different disciplines to be a unified and integrated vision of objectives (internal efficiency and market effectiveness). The modern management accounting conceptions are developed to remove this limitation. Nowadays management accounting systems (using $A B C$ and BSC) allow for an assessment of whether or not the company's goals and future perspectives have been achieved. That is the analysis of the sources of value and the value-creation processes. Thus, modern management conceptions changed the content of management accounting systems from being defined narrowly and tactically to being defined broadly and strategically (see FIGURE 1). It means that besides the roles of data accumulation and transformation, reporting and decision-making, the management accounting system is now focused on strategy implementation.

On the other hand, the adoption of management accounting methods in an organisation directly depends on the specific needs for information of an individual organisation. It presumes that the adoption issue of management accounting methods should be analysed in relation to political, cultural and economic factors, which influence the managerial needs of an organisation. Hence, the implementation of a theoretically descriptive method of management accounting in practice does not automatically imply its availability for decision-making and consequently for value creation as well.

Furthermore, the full system implementation of management accounting conceptions ( $A B C M$, BSC) is typically an expensive investment, as in most cases it becomes not a concept to adopt, but a system to implement (Hicks, 1999). Thus, according to some critics, it is not usually an economically beneficial process. Economic criteria are fairly important in the process of selecting management instrumentation (Palmer \& Parker, 2001; Troxel \& Weber, 1990).

There are cases of organisations that have implemented such techniques, but that do not manage to fully resource all their capacities, or these methods malfunction due to their incompatibility with the specifics of organisational performance, culture and values. 
FIGURE 1: Changing role of management accounting system

\begin{tabular}{|c|c|c|c|c|}
\hline \multirow{2}{*}{$\begin{array}{l}\text { Conceptions } \\
\text { Role }\end{array}$} & \multirow{2}{*}{$\begin{array}{c}\text { Conventional } \\
\text { management } \\
\text { accounting }\end{array}$} & \multicolumn{2}{|c|}{$\begin{array}{c}\text { Activity based } \\
\text { costing/management } \\
A B C / A B C M \\
\end{array}$} & \multirow{2}{*}{$\begin{array}{l}\text { Balanced Scorecard } \\
\text { BSC }\end{array}$} \\
\hline & & Reporting & $\begin{array}{l}\text { Strategy } \\
\text { impleme } \\
\text { ntation }\end{array}$ & \\
\hline $\begin{array}{l}\text { Nature of } \\
\text { information }\end{array}$ & $\begin{array}{l}\text { Focus on the } \\
\text { organisation's past } \\
\text { wealth creation }\end{array}$ & \multicolumn{2}{|c|}{$\begin{array}{l}\text { Focus on information } \\
\text { about company's } \\
\text { value creating } \\
\text { operations }\end{array}$} & $\begin{array}{l}\text { Focus on strategic } \\
\text { advantages and } \\
\text { future outcomes for } \\
\text { the organisation }\end{array}$ \\
\hline Solutions & $\begin{array}{l}\text { Shareholder oriented } \\
\text { solutions } \\
\text { (transactional - } \\
\text { product costing, } \\
\text { pricing, etc.) }\end{array}$ & \multicolumn{2}{|c|}{$\begin{array}{l}\text { Integrated customer- } \\
\text { shareholder oriented } \\
\text { solutions }\end{array}$} & $\begin{array}{l}\text { Integrated customer- } \\
\text { employee- } \\
\text { shareholder oriented } \\
\text { solutions }\end{array}$ \\
\hline
\end{tabular}

\section{Source: Gimžauskienè \& Valančienè, 2007}

Thus, there are authors who propose not to implement concrete theoretically based systems, but to research criteria which could assist in creating specific performance measurement systems in individual organisations (Globerson, 1985; Maskell, 1989; Wisner \& Fawcett, 1991).

This does not automatically imply that the creation of specific systems would disclaim models proposed on the theoretical level as well as applied in practice. Such an approach implies that every organisation should individually deploy and implement principles of theoretical models in accordance with management needs for information.

From one point of view, modern management accounting conceptions might be the precondition for changing the role of management accounting. On the other hand, it depends on consistency with informational requirements, implementation level and the organisation's ability to manage all capacities of these conceptions. Summarising this theoretical review we hypothesise that the availability of information for decision-making depends on the implementation level of the techniques.

\subsection{Implementation studies}

$A B C M$ is the first management accounting method useful not only for costing but for performance measurement as well. The problems of adaptation and implementation of modern management accounting conceptions might be analysed from two different points of view (McGowan \& Klammer, 1997):

- The macro level reflects the organisational view. That means that the adoption process is focused to the advantage of the whole organisation. From this point of view we are talking about a "top-down" direction of organisational change.

- The micro level reflects the individual view. In this conception, adoption is viewed as a means for local problem-solving, such as cost accounting divisions. From this point of view 
we are talking about a "bottom-up" direction of organisational change.

Three trends of $A B C M$ adaptation studies might be distinguished from the macro level point of view: (1) studies of ABCM adoption success factors (Shields, 1995; Swenson, 1995; Forster \& Swenson, 1997; McGowan \& Klammer, 1997;); (2) studies of adoption stages and their success factors (Anderson, 1995; Innes \& Mitchell, 1995; Gosselin, 1997; Krumwiede, 1998); and (3) the availability and functionality of the adopted concept and its impact on performance management and market value (Kennedy \& Graves, 2001). Hence the macro level is more suitable for relations between management accounting and value-creation study.

\section{TABLE 1: Comparison of ABCM, IT, MBO implementation stages}

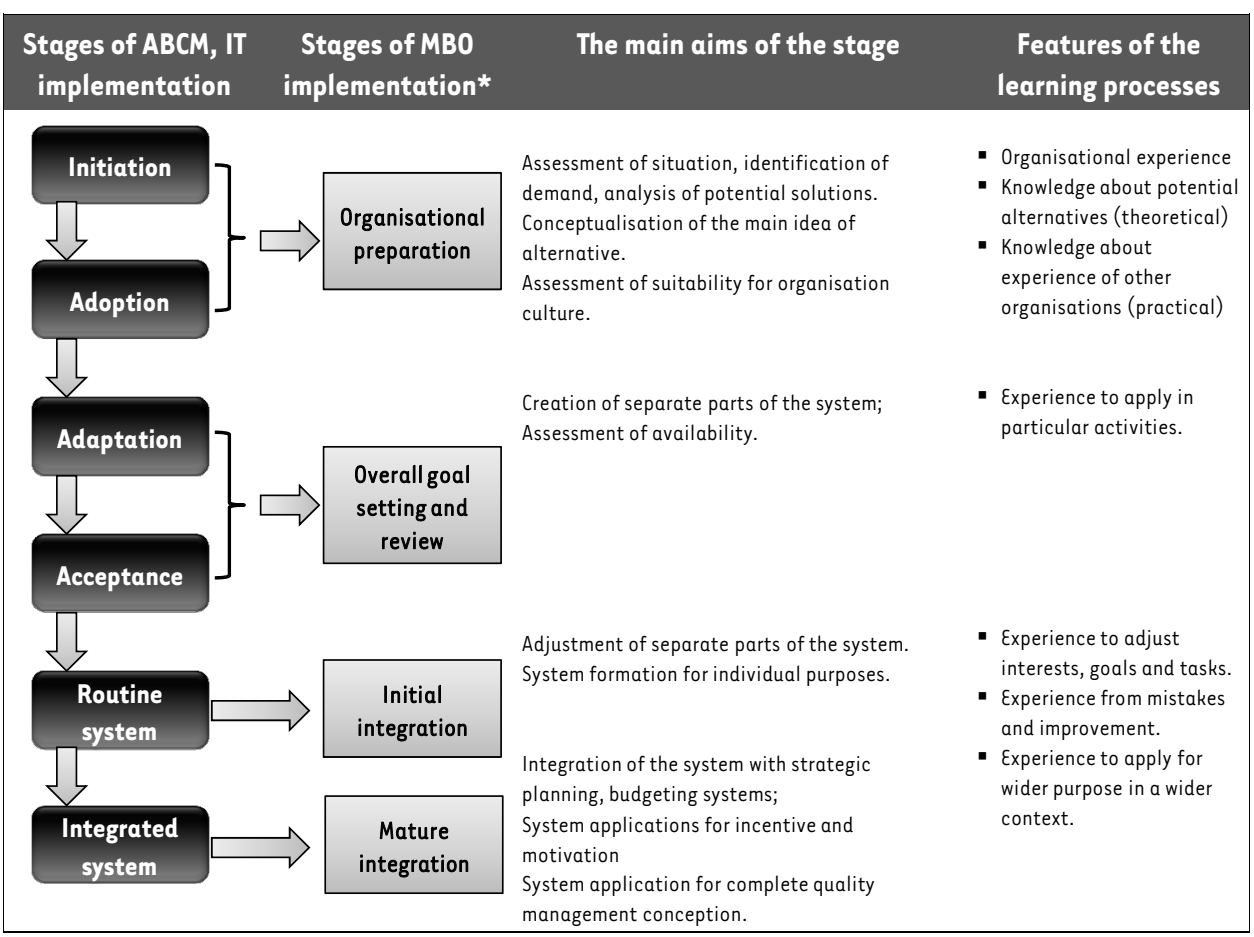

Source: Babcock, Sorensen \& Peter, 1976

Balanced scorecard is another popular concept of management accounting available for performance measurement and management (Atkinson, et al., 1997). This is the fashion that has fascinated modern organisations. Despite a great number of books, articles, presentations, workshops, cases of successful adoption and a wide range of IT solutions it can be maintained that there is a lack of theoretically and empirically grounded studies about BSC adoption stages and featured success factors or problems. The research performed by Malmi (2001) can be mentioned. It was focused on BSC adoption experience and problems. Malina and Selto (2001) analysed BSC as a factor for organisational processes (strategic control and communication). Hoque and James (1994) researched relations between BSC application in practice and such factors as organisation size, product life cycle and market position.

Stages of ABCM adoption are based on changed management theories, IT adoption patterns, and case studies (Anderson, 1995; Krumwiede, 1998). Accordingly, BSC has similar features to MBO. 
Hence it is to be presumed that its adoption process will have similar features. The MBO adoption model is described by Babcock, et al. (1976).

IT adoption stages were offered by Kwon and Zmud (1987). They supplemented Lewin's (1952) three-stage model (unfreeze, change, fix) with traditional IT success factors: acceptance and appliance (Krumwiede, 1998). Adaptation of ABCM can be described in six stages. It covers the range of steps from the rise of initiative till systems integration to existing processes. Those stages are initiation, adoption, adaptation, acceptance, routine system and integrated system.

$A B C M$ adoption studies are usually focused on the early stages or on one of them (Anderson, 1995; Shields, 1995; Innes \& Mitchell, 1995; Gosselin, 1997). But it is essential to analyse the critical success factors of earlier and later stages over quite a long period of time in order to realise all the benefits of the changes. Krumwiede's (1998) study covered the wider range of $A B C M$ adoption stages and critical factors. Besides this he pointed out stages when rejection of the systems is the most likely (adoption, acceptance).

In turn Babcock, et al. (1976) identified four stages of MBO implementation (organisational preparation, overall goal-setting and review, initial and mature integration), the aims of which are related with the six stages analysed by Krumwiede (1998) in the ABCM case. It could be maintained that changes caused by implementation of such concepts are based on the same principles (see TABLE 1). The aims of those stages are different. Some critical success factors such as leader support are applicable to all stages. Other factors such as learning processes are important in all stages as well, but the content of those processes will be different.

Based on the results of the other authors analysed above we have chosen four modern management accounting conception's implementation stages for our study. They will now be briefly discussed.

The main steps of the organisational preparation stage are emergence of the initiative and choice of appropriate solution. The first step (initiative) is the time when an organisation realises the necessity for change, looks for alternative solutions and tries to accustom itself to the inevitability of future changes. The second step (adoption) is the time when an organisation discusses the availability of changes. The main aims of this stage are listed in the table. At this stage three types of rejection are possible:

- when the system is not discussed at all;

- when the system is discussed but an implementation project is not adopted; and

- when the system is discussed but rejected as inapplicable.

The main steps in the fixation stage are adoption and acceptance. Quality and acceptance of creation of parts of the systems are critical at this stage. In the BSC case it means translation of strategy into a set of strategic goals and selection of measures. In the ABCM case it means identification of activities and selection of cost drivers. It is necessary to assess the availability of those means for cost pricing or performance measurement. But information generated with the help of the system is not used for organisational decisions except for financial and accounting divisions. The main problems are the following: a situation when leaders are not supporting the innovation; or vice versa: they try to create the system themselves without involving the lower management level (Roest, 1997; Kaplan, 1999).

More attention should be paid to the later stages, when separate parts of the system are integrated and innovation becomes not a project but a routine, and is applied in a wider context 
because those stages secure the quality of the whole implementation process. They also allow the innovation to be accepted not as a one-off event but as a routine in an organisation.

It is important to adjust the various parts of the system and to adapt them for different users' informational demands. The stage of initial integration could be considered as systems formalisation. It is accomplished when the old system is replaced with the new one, and its application becomes a routine. In the case of management accounting implementation, this means that information generated in the system is available not only for financial or accounting purposes but for other decisions as well. The support of the leaders and learning to apply the system for individual requirements should be mentioned as an important factor. In an ABCM case it means that a division level system will be focused on the analysis of a division's cost and cost drivers. On the organisational level the system will ensure performance measurement and assessment of effectiveness, and generate more integrated information useful for overall process improvement. In the BSC case the goals and measures will be related in cause-effect relations. The organisational level scorecard will meet top management informational requirements and be adjusted with the business units' scorecard.

The stage of mature integration is attained when innovation is adjusted with other management systems (planning, budgeting, incentives and motivation), and is used not for its initial purpose but in a wider context (process improvement, reengineering etc.). Critical factors at this stage are IT level, systems availability for decision-making, strategy implementation and business process reorganisation. Whether or not it has a favourable impact will be dependent on an adequate learning process, and the systems being used for individual requirements.

Summarising the above, it could be maintained that the adoption of a management accounting conception should cover quite a long time period and typical stages of change, because the organisation might disclose all advantages of the system in later stages, when the system is fully integrated. First of all, those advantages are a support for decision-making processes in a wide range of management areas. We argue that the changing role of management accounting might influence value creation, but it is ensured when modern management accounting conceptions are in the integration stages and really working.

\section{RESEARCH METHODOLOGY}

In order to point out the changing role of management accounting in Lithuanian organisations and relations between the management accounting system and value creation, empirical research was performed. Our research consists of two main stages.

- Implementation level of modern management accounting conceptions and the availability of information for decision-making were analysed using quantitative data (survey).

- A deeper analysis was performed in a Lithuanian organisation, revealing relations between value creation and management accounting conceptions implementation level (case study).

The aim of the first stage was to disclose the changing role of management accounting in Lithuanian organisations. This will be grounded in an analysis of the relations between the implementation level of modern management concepts and the range of application areas of information that is generated with the help of those conceptions in Lithuanian organisations (variety of decisions). Prospective results will shed more light on the Lithuanian experience of 
implementing and using modern management accounting conceptions. These results will reveal the context and will be the precondition for the next stage of the research. The direct impact of the management accounting system on value creation is difficult to measure. Quantitative data is insufficient to prove such presumptions, although the indirect influence of management accounting system on value creation becomes evident through substantiating management decision-making. Therefore, the aim of the second stage was to try to answer the research question, "In what way does modern management conceptions influence value creation?" with the help of the qualitative data of a particular organisation.

\subsection{Methodological aspects of the first stage (survey)}

\subsubsection{The development of the hypothesis}

Modern management conceptions influence value creation for shareholders, employees and customers when generated information supports management decisions. On the other hand, the implementation of a modern management accounting conception does not ensure its substantiation and application. The information is suitable for decision-making when conceptual principles of the system really work in an organisation. The declaration that an organisation had fully or partly implemented the conception does not mean that it is true. The question is whether adopters and users of the system understand the main idea and principles of the system, and whether they have succeeded with the realisation of it in practice. The problem is to find out in which cases the declaration about systems implementation remains a declaration, and which factors show that the systems ( $A B C M$ or $B S C$ ) really work.

The main conceptual idea of $A B C M$ is the measurement of costs and performance in each part of an organisation's value chain. It can be presumed that if an organisation measures the costs and performance in its prime activities but not in its supporting activities then it means that the idea of $A B C M$ was not properly understood and implemented. That is the case where the implementation level of $A B C M$ is merely declarative. Based on the presumption listed above, we formulate the first hypothesis:

$H$ (1): The adopters of $A B C M$ measure costs and performance in prime and supporting activities of the value chain more frequently than non-adopters.

The main conceptual idea of BSC is consistency of organisational strategic goals and measures for their achievements. BSC really works when organisational strategy is translated to an appropriate set of goals and measures in different financial and non-financial perspectives. The main steps of the strategy implementation are reflected in a strategy map and tracked with the help of relevant measures. The most likely are situations when an organisation formulates goals, but does not measure the progress or vice versa. The other probable situation is when an organisation has a balanced scorecard (goals and measures in all perspectives), but decisions are based entirely on financial results. Such situations can be considered to represent incomprehension or inadequate application of BSC. The above propositions allow us to formulate the second hypothesis:

H(2): The adopters of BSC adjust goals and measures in financial and non-financial perspectives more frequently than non-adopters.

However, the implementation of a theoretically descriptive method of management accounting 
in practice does not automatically imply its incorporation into decision-making processes in an organisation. There are cases when organisations, which have implemented such techniques, do not manage fully all their capacities. In such situations the management accounting systems $A B C M$ or $B S C$ become ends in themselves, not means to an end. On the other hand, the question is whether this information is accurate, relevant and suitable for decision-making in different management areas. So the presumption that value creation depends on information availability for decision-making and propositions listed above lead us to the third hypothesis:

H (3): Information generated with the help of the adopted systems (ABCM or BSC) are more applicable for decisions in different management areas when the implementation level of the system is not declared but real.

Two independent variables need to be measured in order to confirm or reject the formulated hypothesis:

- level of implementation of modern management accounting conceptions (ABCM, BSC); and

- availability of information for decision-making.

\subsubsection{Content of the questionnaire}

The implementation level of modern management accounting methods was estimated by making the presumption that it depends on knowledge of the conception and implementation experience (full system, partly implemented system, implemented but not used system, failed to implement, known but not implemented, unknown system). Respondents determined the most suitable situation for their organisation. Organisations that declared that they had full or partly implemented the system were presumed to be adapters, while the others were presumed to be non-adapters. In order to determine whether the implementation level was real or declared, respondents were asked additional control questions.

In the $A B C M$ case, respondents ought to check in what parts of the value chain they measure costs and performance. In the BSC case respondents were asked to list appropriate strategic goals (financial, customer, process and learning, and growth) that are formulated and measures that are usable in an organisation. In addition, respondents were asked to check the main steps of strategy formation and implementation process that are usual in the organisation (identification of goals in different financial and non-financial perspectives and selection of measures, analysis of cause and effect linkages between those goals, strategy maps, tasks for teams and employees based on strategic measures). Those steps accordingly reflect the main elements of BSC. In summary, the implementation levels of modern management accounting concepts were researched with the help of two components: declared and real (content of the system) level of implementation.

The situation when an organisation declares fully or partly implemented ABCM but does not measure costs and performance except in one or two activities was presumed to be a declared $A B C M$ implementation level. If an organisation measures costs and performance in more than two activities that situation was deemed to be a properly working $A B C M$ system. Accordingly, the situation when an organisation declares fully or partly implemented BSC, but does not map its strategy and does not adjust its strategic goals and measures was presumed a declared BSC implementation level. The opposite situation was deemed to be a properly working BSC system.

In order to evaluate the availability of information for decision-making, respondents were 
asked to indicate the areas where they usually use it. We have listed 16 possible areas, which cover main management functions planning, control/process improvement, communication/ motivation and relations with the environment (harmonisation of mission, values, vision and strategy, adjustment of strategy and opportunities, adjustment strategy and long-term objectives, tactical tasks formulation and adjustment with objectives, ongoing information about strategic achievements, ongoing information about tactical results, ongoing performance improvement, problems identification and solution, communication with shareholders, quality reward, background for incentive and motivation system, motivation of employees for better results, communication between managers and employees, incentive for collaboration and team work, employees better realisation, communication with government institutions and controllers). The presumption was made that the wider range of application areas means greater availability of information for decision-making.

\subsection{Main steps of the second stage (case study)}

Research questions determined the main steps of the case study. The case study was divided into four steps: choice and overview of the organisation, assessment of value creation and performance measurement system, interpretation of results.

The choice of organisation for the case study was determined by the following criteria: organisation's size, implementation level of both management accounting conceptions, reasons to adopt management accounting conceptions, and the availability of information generated with the help of management accounting conceptions. The criterion of size of organisations was chosen because of the theoretical and practical results of earlier studies, as results of activity based surveys performed in 1996 and 1997 indicate that the size is a significant factor for ABCM conception adoption (Hicks, 1999). Those conceptions are more suitable for large organisations. The changing role of management accounting can be disclosed when both management accounting conceptions are implemented. In order to get significant results ABCM or BSC must be partly or fully implemented in the organisation analysed. The proper interpretation of the conception could be ensured by choosing an organisation that is a member of an international group, in which the adoption of $A B C M$ and BSC was determined by the Patron Company.

The assessment of value creation was performed using publicly available information (financial statements, annual reports for shareholders, annual reports of auditors). Value creation was estimated using DCF, EVA, CVA, and continuing value methods. The assessment of the performance measurement system was performed using the interview method. Respondents were chosen from different management levels. This choice was determined presuming that objective situation could be disclosed summarising information and opinions from different management levels. This ensures an objective view of functional systems' integration and availability at different management levels. Respondents from the lower management level were interviewed using a structured questionnaire (the same that was used in the survey analysed in the previous section). Top managers answered the same questions and made comments, which allowed us to better understand the situation and make interpretations and conclusions. Conclusions and interpretations were made comparing the results of created value and changes in the performance measurement system, determining trends of changing roles of management accounting in time. 


\section{RESULTS AND INTERPRETATION}

The survey covered a total sample of over 200 organisations. 90 completed questionnaires were suitable for future analysis (response rate: $45 \%$ ). It should be noted that $35 \%$ of respondents were organisations that employ between 50 and 300 employees; $6 \%$ employ between 300 and $500 ; 18 \%$ employ 500 and more. Some $48 \%$ of the respondents that took part in the research have been active in the market for ten and more years, while $35 \%$ have been active between five and ten years. This parameter indicates that the practise of management accounting and performance measurement is steady enough. Furthermore, $52 \%$ of the respondents indicated that their revenue in the last year had grown by $50 \%$ and more. Fast growth reflects changes in the structures and processes of an organisation.

TABLE 2: Performance measurement in value chain*

\begin{tabular}{lcc}
\hline & $\begin{array}{c}\text { Non- } \\
\text { adopters }\end{array}$ & Adopters \\
\hline Do not measure performance in value chain & $17 \%$ & $5 \%$ \\
Performance measurement in prime activities (1-3) & $57 \%$ & $26 \%$ \\
$\begin{array}{l}\text { Performance measurement in prime and supporting activities (4 } \\
\text { and more) }\end{array}$ & $26 \%$ & $70 \%$ \\
\hline
\end{tabular}

*indicates significance at .00 level

\section{Source: Own calculations}

About $48 \%$ of the respondents are adopters of $A B C M$. The remainder ( $52 \%$ ) either knew about $A B C M$, but have not attempted to implement it, or did not know about it at all. There are relationships between the implementation level of the $A B C M$ conception and costs as well as performance measurement in the prime and supporting activities of the value chain. The correlation (Pearson's $R=0,467$; Significance at .00 level) is not strong, but it can be maintained that adopters of ACBM measure performance in a wider range of activities more frequently than non-adopters. In some cases the implementation level was declared but not really working. On the other hand the results allow us to propose that there are organisations which measure costs and performance in prime and supporting activities but do not declare ABCM implementation. Therefore, it could be concluded that the first hypothesis is proved (see TABLE 2).

It was difficult to verify the second hypothesis and get statistically reliable results, as the BSC conception has been implemented in only 13 companies (14,4\%). We measured and analysed three variables: BSC implementation level; adjustment of goal and measures; as well as the steps of the strategy implementation process. The correlation (Pearson's $R=0,467$; Significance at .00 level) between BSC implementation level and adjustment of strategic goals is tenuous. The same situation applies in the case of the BSC implementation level and the main steps of the strategy implementation process (Pearson's $R=0,467$; Significance at .00 level). This means that adopters and non-adopters of BSC are looking for ways to track the process of strategy implementation and trying to adjust their strategic goals and performance. On the other hand, there is a correlation (Pearson's $R=0,467$; Significance at .00 level) between adjustment of strategic goals and the measures and main steps of strategy implementation process. According 
to these results it can be maintained that strategic performance measurement (consistency of goals and measures) is at a higher level in those organisations which are mapping their strategy, are formulating goals in different financial and non-financial perspectives, are looking for cause-effect linkages between those goals and are setting tasks for teams and employees. However, this is independent of the implementation level of BSC conception. Those results can be explained in two ways. The first is that most of the respondents represented small- or medium-sized companies, and strategic problems are more typical in big organisations. The second is that the BSC conception was not well known in Lithuanian organisations in 2004 (63\% of respondents did not know about BSC). Currently, the situation has changed but it could be considered as a stage of first experimentation with BSC.

TABLE 3: Adjustment of goals and measures*

\begin{tabular}{lcc}
\hline & Non-adopters & Adopters \\
\hline Not adjusted goals and measures & $4 \%$ & $0 \%$ \\
Adjusted goals and measures (1-3) & $70 \%$ & $62 \%$ \\
Adjusted goals and measures (4-6) & $26 \%$ & $38 \%$ \\
\hline
\end{tabular}

*indicates significance at .09 level

Source: Own calculations

TABLE 4: Steps of strategy implementation process*

\begin{tabular}{lcc}
\hline & Non-adopters & Adopters \\
\hline 0 of 5 steps listed & $14 \%$ & $0 \%$ \\
1 of 5 steps listed & $42 \%$ & $31 \%$ \\
2 of 5 steps listed & $18 \%$ & $38 \%$ \\
3 of 5 steps listed & $18 \%$ & $0 \%$ \\
4 of 5 steps listed & $5 \%$ & $23 \%$ \\
5 of 5 steps listed & $3 \%$ & $8 \%$ \\
\hline
\end{tabular}

*indicates significance at .05 level

Source: Own calculations

In order to prove the third hypothesis we looked for relationships between the ABCM and BSC implementation level and the range of management areas where information is useful for decision-making and the management process. There is quite a strong correlation (Pearson's $R=$ 0,445 ; Significance at .00 level) between the implementation level of concepts ( $A B C M$ and/or $B S C$ ) and the range of management areas where information generated with the help of those conceptions is useful. Organisations that are adopters of both concepts use the information in a wider range of areas than those that are non-adopters. According to the results it can be maintained that information generated with the help of management accounting concepts ( $A B C M$ or $B S C$ ) or another kind of performance measurement process in Lithuania's organisations assists traditional management areas: problems identification solution (43\%) and 
communication with shareholders (42\%). It is logical that respondents don't see management accounting as a means for communication with government institutions and controllers (4\%) (they have financial accounting for this purpose). This information does not serve as a background for incentive and motivation system and communication between managers and employees (about 24\%). The situation of strategic planning is better, because about $35 \%$ of respondents accept the role of management accounting and the performance measurement process for strategy creation, harmonisation with mission, vision, values and adjustment to short- and long-term tasks.

TABLE 5: Availability of information in management areas*

\begin{tabular}{lccc}
\hline & $\begin{array}{c}\text { Non- } \\
\text { adopters }\end{array}$ & $\begin{array}{c}\text { Adopters } \\
\text { ofone } \\
\text { system }\end{array}$ & $\begin{array}{c}\text { Adopters } \\
\text { of both } \\
\text { systems }\end{array}$ \\
\hline Information is not useful in management process & $12 \%$ & $5 \%$ & $0 \%$ \\
Information is useful in 1-4 management areas & $67 \%$ & $43 \%$ & $38 \%$ \\
Information is useful in 5-8 management areas & $19 \%$ & $38 \%$ & $12 \%$ \\
Information is useful in 9 and more management areas & $2 \%$ & $14 \%$ & $50 \%$ \\
\hline
\end{tabular}

*indicates significance at .00 level

Source: Own calculations

The results of this stage of the research revealed the context of the Lithuanian experience in using modern management accounting conceptions and using information generated in it for decision-making. In summary it can be concluded that $A B C M$ is more popular and widely known than BSC. Most ABCM adopters have a proper working system, which ensures costs and performance measurement in prime and supporting activities. A rather different situation is evident in the BSC case. Most of the respondents are not adopters of BSC but solve their strategic problems with the help of their own performance measurement process, which has essential features of BSC. Adopters of ABCM and/or BSC consider the information generated useful for decision making in a wider range of management areas. But do these decisions really influence value creation? Deeper analysis is required to substantiate this kind of relationship.

\section{CASE STUDY}

The case study organisation is a bank, a member of an international group, operating in retail and corporate banking in Lithuania. The bank's mission is to continuously increase the value of the company while recognising customer requirements and offering the best financial solutions. That means that successful business development is focused on customer value creation. On the other hand, one bank's mission statement claims that it believes itself to be the best employer in all geographic regions.

Since 2002 the organisation has been improving its financial results every year. In 2003 the bank earned 61 million Lithuanian Litas (LTL) consolidated net profit - up 21,6\% from the previous year. At the same time, the bank's net interest income increased to LTL 135,8 million - 5,9\% up from 2002. In 2005 the bank earned LTL 137 million in consolidated net profit - LTL 25,9 million (or $23,32 \%$ ) up from 2004, where the net income stood at LTL 111,1 million. At the same time the 
bank's net interest income increased to LTL 245,574 million - 35,62\% up from 2004, while its net fee income increased to LTL 135 million (35,58\% up from the previous year).

Since 2002, return on equity (ROE) has been growing. The ROE rate increased from $16,10 \%$ (2003) to $19,9 \%(2005)$. The major growth $(+2,8 \%)$ was in 2005 .

The successful growth of deposits (LTL 5,6 billion - 25\% up from 2004 and loans (LTL 5,4 billion $54 \%$ ) fuelled the total growth of the bank's assets - it's consolidated assets jumped by $35 \%$ and totalled LTL 8,1 billion at the end of 2004. In 2005 the bank's consolidated assets grew 49\%, to LTL 12,1 billion. This was largely due to the growth of the bank's financial portfolio (LTL 8,4 billion): its share in the total assets went up by 3,2 percentage points to $69 \%$. At the same time, the growth of the financial portfolio rose $56 \%$ from 2004. A further growth in borrowing was fuelled by the development of the Lithuanian economy, optimistic customer expectations and a drop in interest rates because of increased competition. In 2005 borrowing in this country experienced a $52 \%$ jump and totalled LTL 33 billion. The bank's share in the total growth of borrowing stood at $28 \%$, and its market share improved by 1 percentage point up to $26,2 \%$ at year-end 2005. In 2005 customer deposits held with the bank increased $40 \%$ to LTL 7,8 billion, resulting in a 30,3\% growth in the bank's share in the domestic deposit market.

In 2005, the bank strengthened its leadership position in the domestic personal lending business. Its personal loans portfolio doubled and reached LTL 2,6 billion, while the market share improved by 1,3 percentage points and grew to $30,3 \%$. In 2005 the fastest growth rates were recorded in the area of home loans - the bank's home loans growth rates accelerated by $26,3 \%$ and hit a $109 \%$ annual growth level.

In summary, it can be stated that the chosen organisation is one of the most successful and largest financial institutions in Lithuania. The figures also demonstrate the organisation's stability and strength. The bank's network and subsidiaries enable it to offer customers professional and helpful service, convenient access to the bank's products and services for competitive prices, and the provision of all financial services from one place. It composes essential assumptions for successfully operating in a growing market.

\subsection{Assessment of value creation}

In this case study the company investigated is not a listed company. For this reason value creation of the company should be calculated on the basis of internal information. Value creation can be estimated using discounted cash-flow methods (DCF), economic value added (EVA), cash value added (CVA), and continuing value methods. CVA and EVA were used to measure performance objectively. In the case of CVA we evaluated operating cash flows, sinking funds depreciation and cost of capital. In the case of EVA, we evaluated the return on invested capital and weighted average cost of capital (WACC). But neither of these methods contained information about expectations. That is why we measured performance using continuing value and DCF methods. These methods evaluate expectations such as growth of return on new investment and net operating profit after taxes (NOPAT). Trying to compare valuation results also, we calculated the company's book value.

According to the bank's financial statement data and our calculation results, the company's book value and EVA has increased over the last three years (see TABLE 6). The successful growth of deposits impacted the total growth of the bank's assets. It ensured the stable growth of the bank's book value ( $36 \%$ in 2004 and $46 \%$ in 2005). 
The bank earned LTL 85,4 billion economic profit or EVA in 2004. This means LTL 25 billion (or 42\%) up from 2003. In 2005 EVA was LTL 103,7 billion but it increased only $21 \%$ from 2004 . The main reason for such results was the increased rate of WACC (1\%). The negative value of CVA in 2005 indicates that sinking funds depreciation and capital costs grew faster than operating cash flow.

DCF valuation results showed that the organisation generates positive free cash flows during every period and this confirms its ability to create value. Continuing value decreased only in 2005 (24,9\%). The main reason for this result was the decreased rate of NOPAT growth because of increased competition, which caused a drop in interest rate.

Summarising the bank's valuation, the following conclusion was formulated: three methods of performance valuation confirm the bank's ability to create value, but all the methods indicate that the value growing rate is decreasing. According to the results it could be stated that changes in the management process influenced value creation. On the other hand, those numbers do not show in what way this value was created. In order to find out how value creation drivers are managed, the performance measurement system must be assessed.

TABLE 6: Performance valuation results (thousands LTL)*

\begin{tabular}{lrrr}
\hline & 2003 & 2004 & 2005 \\
\hline Book value & 441874 & 601631 & 879998 \\
Continuing value & 118490 & 278895 & 210921 \\
CVA & 9661 & 14737 & -9270 \\
EVA & 60180 & 85493 & 103740 \\
DCF & 83814 & 112247 & 124213 \\
\hline
\end{tabular}

* Calculated correlation coefficient between EVA and book value of company was 0.9693 , but the results are doubtful. Unreliability of results can be explained by the insufficient amount of data. Level of significance is higher than 0.05 (approx. Sig $p=.158155$ )

Source: Own calculations

\subsection{Assessment of performance measurement system}

Research into the performance measurement system was performed from May 2003 until February 2004. At this time four respondents of different management levels were interviewed (manager of customer service centre in Vilnius; expert of financial analysis and planning department in Vilnius; (EO of Klaipeda region and a member of the directors' board in Vilnius). This choice was determined by a presumption that the objective situation could only be revealed using summarising information and opinion from different management levels. Respondents at lower management levels were interviewed using a structured questionnaire (the same that was used for the survey analysed in the previous section). Top managers answered the same questions and made comments, which enabled us to better understand the situation and make interpretations and conclusions.

Consideration about $A B C M$ implementation was started in the Patron Company in 1997. The implementation project was problematic because of the organisation's structural changes, continual introduction of new products, complicated allocation of IT costs, and an overly 
complex structure of activities. Until 2004, ABCM was used only for costing in the Patron Company. The functioning system had serious disadvantages, namely, disproportional allocation of IT expenses, and unclear identification of costs (products, services and distribution channe/s), so the system was applied in retail banking only. An activity-based costing implementation project in Lithuania was started in 2003. A new project group was established in order to meet the goal of applying ABCM for EVA calculations and IT expenses allocation for business units, bank products and customers groups from 2004.

The financial analysis and planning department was responsible for success of the project. This was the reason for starting our research with an expert from this department in May 2003. At this time the $A B C$ system was declared as partly implemented. Our aim was to indicate in what parts of the value chain cost and performance were measured first. Respondents listed human resource management activities and product creation.

The actuality of human resource management activity was determined by the fact that the bank became privately owned in 2001 . The bank started the reorganisation and optimisation of its branch network in 2002. The results of reorganisation are visible: in 2003 the bank consisted of 150 bank offices with 6135 employees, while in 2005 the organisation consisted of 120 bank offices with 2500 skilled and professional employees. Interest to product creation activity is suited to e-business and e-banking entry to the Lithuanian financial market. This was the reason that a wide range of new products and complexity of their cost estimation and pricing outweighed the costing problems of traditional products and services. The next intended steps were to include marketing and development of infrastructure activities.

The manager of the customer service centre was interviewed in December 2003. At this stage we expected to review the progress of implementation, and ascertain whether the plans developed by an expert in the financial analysis and planning department had been realised. The lowest management level was chosen because of the requirement of finding out how useful the $A B C$ system was within the organisation. At this point we realised that costs and performance measurement is accomplished in product and service delivery, marketing, staff management as well as infrastructure development activities. Product creation activity still remained in process. These kinds of problems are suitable for the head office, whereas the lower level of staff could have been insufficiently informed.

Respondents from the highest management level were interviewed in the last step of research. In February 2004 they pointed out all ten of the listed parts of the value chain. It could be maintained that the $A B C$ system covered all processes of the value chain. But it was more useful for costing and pricing decisions than process improvement decisions. Thus, activity-based costing conception became a properly working system, and it could be stated that the second implementation stage (fixation) was over. However, process improvement decisions relating to activity-based management were in the initial stage.

It was quite a different situation with BSC implementation. BSC conception was enforced by the Patron Company, as the bank is a member of an international group. Thus BSC goals and measures were the same as in the entire group. Interviews performed in May and December 2003 disclosed similar situations. Respondents from the customer service centre, financial analysis and the planning department listed the importance of all kinds of goals from financial, customer, internal process, and learning/growth perspectives, as well as marked absence of measures for internal processes, human resource management and development. On the other hand it was interesting that neither of the respondents understood that such measures were suited to the BSC conception. They even did not know about the existence of such a system in 
their organisation. This allowed us to draw the conclusion that at this time BSC had not been properly introduced to the lower levels of the organisation.

The essence of the BSC conception is strategic control. Top level respondents have enough competence to discuss BSC. The exceptional feature of a balanced scorecard in the company is the importance of EVA. It means that financial goals are placed first. In the opinion of the top level respondent the goals and measures of other perspectives are adjusted to the financial ones. He pointed out that strategy and strategic goals are discussed at the top level, but are not communicated to the lower management levels. Cause and effect linkages are discussed but not tracked in the strategy map. The top level respondent marked the absence of measures for internal and learning/growth perspectives related to employee training, education and evaluation. At the time that the research was conducted, the incentive and motivation system was based on financial measures. This can be explained by pointing out that, at that time, the realisation of market opportunities and growth was more important. Therefore, internal problems, including human resource development, were delayed for the future. At this point it could be maintained that real performance and its measurement were mismatched as was declared in the mission statement "to be the best employer in all geographic regions."

On the other hand the top level respondent said that the organisation had not formalised its strategy as it is a member of an international group and follows the general long-term guidelines of the group. Based on the mission and vision statement it could be supposed that the most appropriate strategy is differentiation (customer value creation). In this case customer management processes (improvement of solutions, customer services, relationship management, and information services) are the most important looking for cause and effect linkages between financial, internal process, and learning goals. Consequently measures should be selected for such kind of goals.

To summarise the BSC implementation experience, it can be maintained that the preparation stage was missed, and fixation stage in its initial phase as the BSC system was enforced by the Patron Company. The Patron Company is a bank. Thus, the goals and measures were the same as well as priorities of valuation. At this time BSC conception might be considered as a formal partly accepted system.

The same opinion was noticed when the availability of information generated with the help of $A B C$ and $B S C$ systems was evaluated. Information generated with the help of $A B C M$ is useful for middle level managers. It is a basis for product creation, economic effect, and pricing decisions. A distinctive feature of this system is that information generated with $A B C M$ is used for EVA calculations and monitoring, as in this organisation, EVA is the most important measure of performance evaluation. All of the respondents pointed out that information is useful for shareholder and problem identification and solving as well as improvement of the value creation process. The respondents agreed that it might be the basis for incentives and motivation system. At the moment, BSC goals and measures are used for task formulation and employee evaluation but not for incentives and motivation. Respondents from the top level emphasised that real working systems are useful for strategy formation and adjustment with the values, mission and vision, tracking strategic achievements, and tactical results. The fact that all respondents believe that these systems might help employees feel appreciated and realise their potential better matches the intention to be the best employer stated in the mission.

Resuming the results of the case study, it could be stated that both ( $A B C M$ and $B S C$ ) conceptions have not reached integration stages. This conclusion was made because we noticed the absence of communication between top and lower management levels (the lower level does not know 
about the systems, especially BSC; the top level manager does not see the requirement to communicate strategic information to the lower levels). On the other hand, information is the basis for cross-functionality and through different management levels communication is created. Essentially it can be maintained that $A B C M$ and BSC have changed the role of management accounting in particular organisations. Measures such as growing market share and number of customers, and a wide range of new products and services at competitive prices, creates value for the customer. Upgraded financial results reveal shareholder value creation. Still, value creation for employees is not fully realised and is delayed for the future.

\section{CONCLUSIONS AND RECOMMENDATIONS}

On the basis of the theoretical propositions and the results of the empirical research it can be stated that modern management accounting conceptions might be a precondition for the changing role of management accounting.

The role of modern management accounting systems has evolved from data accumulation to strategy implementation. It means that, currently, the role of management accounting has changed its focus from a shareholder orientation to customer-employee-shareholder integrated solutions. Those solutions are focused on permanent monitoring, measurement and management of strategic advantages and future outcomes (translation of strategy into appropriate set of goals and measures, strategy mapping etc.).

The results of the empirical research demonstrated the changing role of management accounting in Lithuanian organisations. Nevertheless, the performance measurement process in these organisations assists traditional management areas: problem identification and solving, and communication with shareholders. It can be stated that the performance measurement process provides the background for an incentive and motivation system, and for communication between managers and employees.

Theoretical propositions and the results of the empirical research allow us to maintain that the adoption of modern management accounting conceptions could influence value creation, but it depends on the implementation level and an organisation's ability to manage all the capacities of these conceptions.

The availability of information generated with the help of ABCM and BSC conceptions is more available in later stages of the implementation process, namely, initial and mature integration. At this time systems become routine and most learning processes are focused on application for individual purposes and in a wider context (process improvement, engineering etc.).

The results of the empirical research indicate that there is quite a strong correlation between implementation level of conceptions ( $A B C M$ and or $B S C$ ) and a range of management areas where information generated with the help of those conceptions is useful. The case study organisation has started integration stages and has created an information basis for crossfunctionality and communication that cuts through the different management levels, but at the same time there is an absence of communication between the top and lower management levels.

Adopters of $A B C M$ and $B S C$ consider information generated with the help of modern management accounting techniques useful for decision-making, thus for value creation as well. On the other hand it is difficult to determine clear relations between value creation and changes in the management accounting system. However, trends of increasing value creation and positive 
changes in performance measurement systems supporting a wide range of decision-making areas in the case study organisation might be coherent.

Based on the conclusions listed above, some recommendations for practitioners who are implementing or are going to implement modern management accounting conceptions in their organisations can be provided.

The starting point to achieve a fully implemented and functional system is to choose the way the conception is to be adopted. Two different points of view should be mentioned:

- implementation of modern management accounting conceptions as a result of external pressure; and

- internal position which is based on the informational demand of managers. The results of the empirical field study proved that the internal position is the most appropriate.

The quality of value chain analysis and appropriate measures in each part of it are the leading factors of ABCM system's clarity and functionality. This depends on the involvement of people in the organisations, not only accountants but process people as well. Although $A B C M$ creates value when it is used - not just for product or other object (customer) costing but for cost structure and performance improvement in each part of the value chain - it also allows for an analysis of the consumption of the resources used for different activities and results achieved (activity drivers) and for budgeting as well.

A fully implemented and functional BSC system becomes a real strategic management tool and is able to track the changes of strategic achievements and causal relations between them. Strategy should be divided into strategic goals, measured and executed in different levels of the organisation. The involvement of people from different management levels is a very important factor. BSC creates value when it becomes not just a set of financial and non-financial measures for top managers, but a system linked with causal relations for performance measurement and rewards in all levels and different units of an organisation.

In summary, it can be stated that ABCM and BSC provide opportunities and ways to perform, and later help to measure and, based on that measurement, assure rewards for customers, employees and shareholders. This means that the adaptation of these management accounting conceptions enables a value creation cycle in the organisation.

\section{REFERENCES}

Alam, M. (1997). Budgetary process in uncertain contexts: a study of state-owed enterprises in Bangladesh. Management Accounting Research, 8(2), pp. 147-167.

Anderson, S.W. (1995). A framework for assessing cost management system changes: The case of activity-based costing implementation by General Motors, 1986-1993. Journal of Management Accounting Research, 7, pp. 71-51.

Anderson, S.W., \& Lannen, W.N. (1999). Economic transition, strategy and the evolution of management accounting practices: the case study of India. Accounting, Organizations and Society, 24(5/6), pp. 379-412. 
Atkinson, A.A., Balakrishan, R., Booth, P., Cote, J.M., Groot, T., Malmi, T., Roberts, H., Uliana, E., \& Wu, A. (1998). New directions in Management Accounting Research. Journal of Management Accounting Research, 9, pp. 79-107.

Babcock, R., Sorensen, J. \& Peter Jr., F. (1976). A Long-Range Approach to MBO. Management Review, 65(6), pp. 24-32.

Balakrishan, R., Linsmeier, T. \& Venkatachalan, M. (1996). Financial benefits from JIT adoption: Effects of customer concentration and cost structure. The Accounting Review, 71(2), pp. 229245.

Blattberg, R.C., Getz, G., \& Thomas J.S. (2001). Customer equity. Building and managing relationships as valuable assets. Boston: Harvard Business School Press.

Burns, J. \& Scapens, R.W. (2000). Conceptualizing management accounting change: an institutional framework. Management Accounting Research, 11(1), pp. 3-25.

Caru, A. \& Cugini, A. (1999). Profitability and customer satisfaction in services. International Journa/ of Service Industry Management, 10(2), pp. 132-156.

Coates, J.B., Davis, E.W., Emmanuel, C.R., Longden, S.G. \& Stacey, R.J. (1992). Multinational Companies Performance Measurement Systems: International Perspectives. Management Accounting Research, 3(2), pp. 133-150.

Cobb, I., Helliar, C. \& Innes, J. (1995). Management accounting change in bank. Management Accounting Research, 6(2), pp. 155-175.

Demsi, J.S. \& Bainen, S. (1987). Economically optimal Performance. Evaluation and Control Systems. Journal of Accounting Research, 13(3), pp. 184-220.

Dent, J. (1996). Global competition: challenges for management accounting and control. Management Accounting Research, 7(3), pp. 247-270.

Forster, G. \& Swenson, D.W. (1997). Measuring the success of activity- based cost management and its determinants. Journal of Management Accounting Research, 9(1), pp. 107-139.

Globerson, S. (1985). Issues in developing a performance criteria system for organization. International Journal of Production Research, 23(4), pp. 639-646.

Gosselin, M. (1997). The effect of strategy and organizational structure on the adoption and implementation of activity based costing. Accounting Organizations and Society, 22(2), pp. 105-122.

Granlund, M. \& Lukka, K. (1998). Towards increasing business orientation: Finish management accountants in a changing culture context. Management Accounting Research, 9(2), pp. 185211.

Granlund, M. \& Lukka, K. (1998). It's a small world of Management Accounting Practices. Journal of Management Accounting Research, 10(1), pp. 153-179.

Grönroos, C. (1997).Value-driven Relational Marketing: from Products to Resources and Competencies. Journal of Marketing Management, 13(5), pp.407-419.

Haldma, T. \& Laats, K. (2002). Contingencies influencing the management accounting practices of Estonian manufacturing companies. Management Accounting Research, 13(4), pp. 379-401.

Heskett, J.L. \& Sasser, Jr. W.E., Schlesinger, L. A. (1997). The Service Profit Chain. New York: The Free Press. 
Hicks, D.T. (1999). Activity based costing. Making it work for small and mid-sized companies. New York: John Wiley \& Sons, Inc.

Hoque, Z. \& Hopper, T. (1994). Rationality, accounting and politics: a case study of management control in Bangladesh Jute Mill. Management Accounting Research, 5(1), pp. 5-30.

Innes, J. \& Mitchell, F. (1995). A survey of activity- based costing in the U.K.'s largest companies. Management Accounting Research, 6(2), pp.137-153.

Innes, J.\& Mitchell, F. (1990). The process of change in Management Accounting: some field study evidence. Management Accounting Research, 1(1), pp. 3-19.

Kaplan, R..S. (1999). Mobil USM\&R: (A) Linking the Balanced Scorecard. Harvard Business School Press, September, No 9-197-027, pp.1-7.

Kellet, B.\& Sweeting, R.C. (1991). Accounting innovations and adaptations: a UK case. Management Accounting Research, 2(1), pp. 15-26.

Kennedy, T. \& Graves, J.A. (2001). Impact of activity- based costing techniques on firms' performance. Journal of Management Accounting Research, 13(1), pp. 19-45.

Krumwiede,K.R. (1998). The implementation stages of activity- based costing and impact of contextual and organizational factors. Journal of Management Accounting Research, 10(1), pp. 239-277.

Laitinen, દ.K., (1999). Management Accounting Change in Finish Small Technology Companies. Accounting Perspectives on the Threshold of the $21^{\text {st }}$ Century: Proceedings of the conference. Tartu: Tartu University, 1999, pp.72-80.

Libby, T. \& Waterhouse, J.H. (1996). Predicting Change in Management Accounting Systems. Journal of Management Accounting Research, 8(1), pp. 137-150.

Luther, G. \& Longden, S. (2001). Management accounting in companies adapting to structural changes and volatility in transition economies: a South African study. Management Accounting Research, 12(3), pp. 299-320.

Malina, M.A. \& Selto, F.H. (2001). Communicating and Controlling Strategy: An Empirical Study of the Effectiveness of the Balanced Scorecard. Journal of Management Accounting Research, 13(1), pp. $48-90$.

Malmi, T. (2001). Balanced Scorecard in Finnish companies: A research note. Management Accounting Research, 12(2), pp. 207-220.

Martin, J. \& Pett, J.W. (2000). Value based management. Boston: Harvard Business School Press.

Maskell, B. (1988). Relevance Regained - an interview with Professor Robert S Kaplan. Management Accounting, September, pp.38-42.

McGowan, A.S. \& Klammer, T.P. (1997). Satisfaction with activity- based cost management implementation. Journal of Management Accounting Research, 9(1), pp. 217-237.

McNair, C.J. \& Polutnik, L. (2001). Cost management and value creation: the missing link. The European Accounting Review, 10(1), pp. 33-50

Novack, R.A., Langley, C.J. \& Rinehart, L.M. (1995). Creating logistics value: theme for the future. Oak brook: Council of Logistics Management. 
Palmer, દ. \& Parker, D. (2001). Understanding performance measurement systems using physical science uncertainty principles. Journal of Organizational Change Management, 21(7), pp. 981999.

Payne, A. \& Holt, S. (2001). Diagnosis of customer value: Integrating the value process and relationships management. British Journal of Marketing, 12(3/4), pp.159-182.

Payne, A., Holt, S. \& Frow, P. (2001). Relationship Value Management: Exploring the Integration of employee, Customer and Shareholder Value and Enterprise Performance Models. Journal of Marketing Management, 17(7/8), pp.785-817.

Reichheld, F.F. (1996). The Loyalty Effect. Boston: Harvard Business School Press.

Roest, P. (1997). The golden rules for implementing the Balanced Scorecard Information Management \& Computer Security, 5(5), pp. 163-165.

Shields, M.D. (1995). An empirical analysis of firms' implementation experiences with activity-based costing. Journal of Management Accounting Research, 7(1), pp.148-166.

Simons, R. (2000). Performance Measurement and Control Systems for Implementing Strategy: Text and cases. New Jersey: Prentice Hall.

Stewart, G.B. (1991). The Quest for Value. New York: Harper Collins Inc.

Storbacka, K. (1997). Segmentation based on customer profitability: retrospective analysis of retail bank customers. Journal of Marketing Management, 13(5), pp.479-492.

Swenson, D.W. (1995). The benefits of activity- based cost management to manufacturing industry. Journal of Management Accounting Research, 7(1), pp.167-180.

Troxel,R.B. \& Weber,M.G. (1990). The evolution of activity-based costing. Journal of Cost Management, Spring, pp.14-22.

Valančienė, L. \& Gimžauskienė, દ. (2007). Changing role of management accounting: Lithuanian experience case studies. Engineering economics (Inžinerine ekonomika), 5(55), pp. 16-23.

Wenner, D.L. \& LeBer, R.W. (1989). Managing for Shareholder Value - From Top to Bottom. Harvard Business Review, 11(12), pp. 52-66.

Wisner, J.D. \& Fawcett, S.E. (1991). Link firm strategy to operating decisions through performance measurement. Production and Inventory Management Journal, 32(3), pp. 5-11.

Wnuk, T. \& Sobanska, I. (2001). Management Accounting Practice in Poland. Economics and management' 2001. International scientific conference proceedings: Kaunas, Technologija, pp. 225-232.

Woodruff, R. B. (1997). Customer Value: The Next Source of Competitive Advantage. Journal of the Academy of Marketing Science, 25(2), pp.139-153. 
E Gimžauskienè \& L Valančienè 